\title{
A new species of Acestridium Haseman, 1911 (Loricariidae: Hypoptopomatinae) from the Eastern Amazon basin, Brazil
}

\author{
Mónica S. Rodriguez and Roberto E. Reis
}

Acestridium triplax, new species, is described from the Amazon River basin in Pará State, Brazil. The new species can be distinguished from all its congeners by having one series of middle abdominal plates between the lateral abdominal plates (vs no abdominal plates between the lateral abdominal plates).

Acestridium triplax, nova espécie, é descrito do rio Amazonas, Estado do Pará, Brasil. A espécie nova pode ser distinta de todas as suas congêneres por possuir uma série de placas abdominais médias entre as placas abdominais laterais ( $v s$ sem placas abdominais médias entre as placas abdominais laterais).

Key words: Freshwater fishes, Neotropical, Taxonomy.

\section{Introduction}

Species of Acestridium Haseman, 1911 are highly distinctive, small sized, specialized loricariid catfishes, which have very narrow body, snout prolonged with a distinctive anterior spatulate projection, and usually green color in life. Acestridium was diagnosed by Schaefer (1991) based on the following characters: ten principal caudal-fin rays; plates at anterior snout margin forming conspicuous spatulate projection; head and body very slender, depressed; dorsal surface of head and trunk with longitudinal ridges; dorsal fin placed posteriorly, well beyond pelvic fin and just anterior to anal-fin origin; adipose fin absent; dermal plates anterior to first dorsal-fin proximal radial expanded, bearing ventromedial keel contacting the dorsal margin of the neural arches of the vertebrae six through twelve; and ridge of bone on the ventral surface of the lateral ethmoid contacting the metapterygoid channel reflected mesially.

Currently, four species of Acestridium are described: $A$. discus Haseman, 1911, A. dichromum Retzer, Nico \& Provenzano, 1999, A. martini Retzer, Nico \& Provenzano, 1999, and A. colombiensis Retzer, 2005. In this paper, we describe a new species of Acestridium first collected by Wolmar B. Wosiaki and Luciano F. Montag in the lower Amazon River basin in Pará, Brazil, during the course of an environmental impact evaluation and subsequent environmental monitoring for a bauxite mining company.

\section{Material and Methods}

The morphometric variables were measured with a digital caliper (0.1 mm precision). Most measurements follow Boeseman (1971), except for pectoral-fin origin to pelvic-fin origin distance, eye to dorsal-fin origin distance, oral disk width, and counts of teeth and plates (which follow Retzer et al., 1999). Body depth at anal-fin origin is included as a new measurement. Names and counts of lateral, abdominal, and rostral plates follow Schaefer (1997). Fishes were cleared and double-stained (c\&s) with Alcian Blue for cartilage and Alizarin Red for bone according to procedures of Taylor \& Van Dyke (1985). In the lists of material examined, museum abbreviations and catalog numbers are presented first, followed by the number of specimens examined, number of cleared and stained specimens, size range and locality. Number of measured specimens and range of standard length (SL) between parenthesis, geographical coordinates, date of collection, and collectors are added for the new species. Abbreviations for institutions follow Reis et al. (2003).

\section{Results}

Acestridium triplax, new species

Fig. 1

Holotype. MPEG 13355, 55.5 mm SL, female, Brazil, Pará, Município de Juruti, igarapé Mutum, tributary to rio Aruã, a

Laboratório de Ictiologia, Pontifícia Universidade Católica do Rio Grande do Sul. P.O. Box 1429, 90619-900 Porto Alegre, RS, Brazil. rodriguez.monica@yahoo.com.ar 
tributary to rio Branco, a tributary to rio Aripiuns, itself a tributary to the lower rio Tapajós, $2^{\circ} 36^{\prime} 45^{\prime \prime S} 56^{\circ} 11^{\prime} 37^{\prime \prime W}, 11$ Dec 2006, L.F. Montag.

Paratypes. Brazil, Pará, Juruti: MCP 41745, $9+1$ c\&s, 41.8-52.8 $\mathrm{mm}$ SL (2, 51.7-52.8 mm SL) and MPEG 12461, 9, 28.9-50.4 mm SL (1, 50.4 mm SL), same data as holotype. MPEG 10123, 5, 27.8$42.7 \mathrm{~mm}$ SL and MPEG 10124, 10, 27.6-49.5 mm SL (2, 46.6-49.5 $\mathrm{mm}$ SL), same locality as holotype, 3 Mar 2006, L.F. Montag. MPEG 12476, 5, 37.4-46.8 mm SL (1, $46.8 \mathrm{~mm}$ SL), same locality as holotype, 6 Aug 2004, W. Wosiacki. AMNH 240826, 10, 41.1$51.8 \mathrm{~mm}$ SL (2, 50.9-51.8 mm SL), igarapé Socó Barroso, 2²7’05"S $56^{\circ} 11$ '35"W, 12 Dec 2006, L.F. Montag. MPEG 10122, 3, 48.949.1 mm SL (2, 46.9-47.5 mm SL), igarapé Socó Barroso, 2²7'05"S $56^{\circ} 11^{\prime} 35^{\prime \prime W}, 4$ Mar 2006, L.F. Montag. MPEG 12462, 5, 34.8$50.0 \mathrm{~mm} \mathrm{SL}(1,50.0 \mathrm{~mm} \mathrm{SL})$, rio São Francisco, $2^{\circ} 10^{\prime} 44^{\prime \prime S}$ 5604'37"W, 14 Dec 2006, L.F. Montag. AMNH 240827, 10, 32.4$50.2 \mathrm{~mm} \mathrm{SL}(1,48.5 \mathrm{~mm} \mathrm{SL})$, creek at $2^{\circ} 36^{\prime} 45^{\prime \prime S ~} 56^{\circ} 11^{\prime} 37^{\prime \prime} \mathrm{W}, 2$ Aug 2004, W. Wosiacki. MCP 41746, $8+2$ c\&s, 30.6-52.0 mm SL (2, 49.1-50.8 mm SL), creek at 2 ${ }^{\circ} 36^{\prime} 45^{\prime \prime} \mathrm{S} 56^{\circ} 11^{\prime} 377^{\prime \prime W}, 3$ Sep 2002 , W. Wosiacki. MPEG 12614, 8 + 2 c\&s, 41.0-53.5 mm SL (1, 53.5 $\mathrm{mm} \mathrm{SL}$ ), creek at $2^{\circ} 36^{\prime} 45^{\prime \prime S} 56^{\circ} 11^{\prime} 37^{\prime \prime} \mathrm{W}, 8$ Sept 2002 , W. Wosiacki. ANSP 187168, 10, 36.7-55.4 mm SL (2, 50.6-55.4 mm SL) and MPEG 12492, 4, 23.8-28.9 mm SL and MPEG 12493, 4, 27.4-52.3 $\mathrm{mm}$ SL $(1,52.3 \mathrm{~mm} \mathrm{SL})$, creek at 2०36'45"S 56 $16^{\circ} 11^{\prime} 37^{\prime \prime W}, 9$ Sep 2002, W. Wosiacki. ANSP 187167, 11, 29.2-51.0 mm SL (3, 46.5$51.0 \mathrm{~mm} \mathrm{SL})$ and MPEG 12451, 10, 32.3-49.1 mm SL (3, 47.1-49.1 mm SL), creek at 2'34'52"S 55 54' 11 "W, 14 Dec 2006, L.F. Montag. MPEG 12467, 10, 35.4- 48.0 mm SL (3, 45.3-48.0 mm SL), creek at $2^{\circ} 33^{\prime} 40^{\prime \prime S ~ 5554 ' 11 " W, ~} 15$ Dec 2006, L.F. Montag. MPEG 12468 , 10, 34.1-53.3 mm SL (1, $53.3 \mathrm{~mm} \mathrm{SL})$ and MPEG 12475, 7, 34.1$52.3 \mathrm{~mm} \mathrm{SL}(1,52.3 \mathrm{~mm} \mathrm{SL})$, creek at $2^{\circ} 27^{\prime} 54^{\prime \prime S} 56^{\circ} 00^{\prime} 25^{\prime \prime} \mathrm{W}, 12$ Dec 2006, L.F. Montag. MPEG 12453, (1, $53.4 \mathrm{~mm} \mathrm{SL})$, creek at 2²7'54"S 56º0’25"W, 13 Nov 2006, L.F. Montag.

Diagnosis. The new species differs from all other species of Acestridium in having one series of middle abdominal plates between the lateral abdominal plates (vs middle abdominal plates absent in remaining species). It is also distinguished from $A$. dichromum (the most similar species) in having a small and rounded snout-tip spatulate projection (vs large and oval spatulate projection; Fig 2), a thick pectoral-fin spine without serrae or slightly serrated ( $v s$ very thick and strongly serrated in the inner face; Fig. 3), posterior most lateral abdominal plate small ( $v s$ large; Fig. 4), and preanal plate approximately rectangular, with short lateral projections ( $v s$ preanal plate cross-shaped, with large lateral projections; Fig. 4).

Description. Morphometric data given in Table 1. Head, trunk, and caudal peduncle strongly depressed, elongate, and narrow. Body width $14.9-20.8 \%$ of postdorsal length (mean= $17.8 \%$ ). Dorsal surface of body straight or slightly concave from snout tip to eye, straight or slightly convex from eye to dorsal fin, straight from dorsal fin to penultimate plate of caudal peduncle.

Body covered with bony plates except for ventral part of head and very narrow area surrounding pelvic-fin base and anus. Body plates uniformly covered by small odontodes, arranged in longitudinal rows.

Profile of head triangular with round spatulate projection on tip of snout in dorsal view. Spatulate projection covered by pair of rostral plates with large odontodes. Eyes placed laterodorsally, not visible from below; iris operculum present. Snout tip with small naked area (seen in cleared and stained specimens). One rostral plate and two postrostral plates on each side. Postrostral plates and cheek plate bent ventrally and visible in ventral view, cheek plate with canal from fifth infraorbital. Posterior portion of postrostral plates not united at midline ventrally. Mouth rounded, with globular papillae on both upper and lower lips. Oral disc width between $12.9-18.7 \%$ of postdorsal length $($ mean=15.8). Maxillary barbel shorter than eye diameter. Premaxilla with 22 to $30($ mean $=26, n=31)$ bilobed teeth in

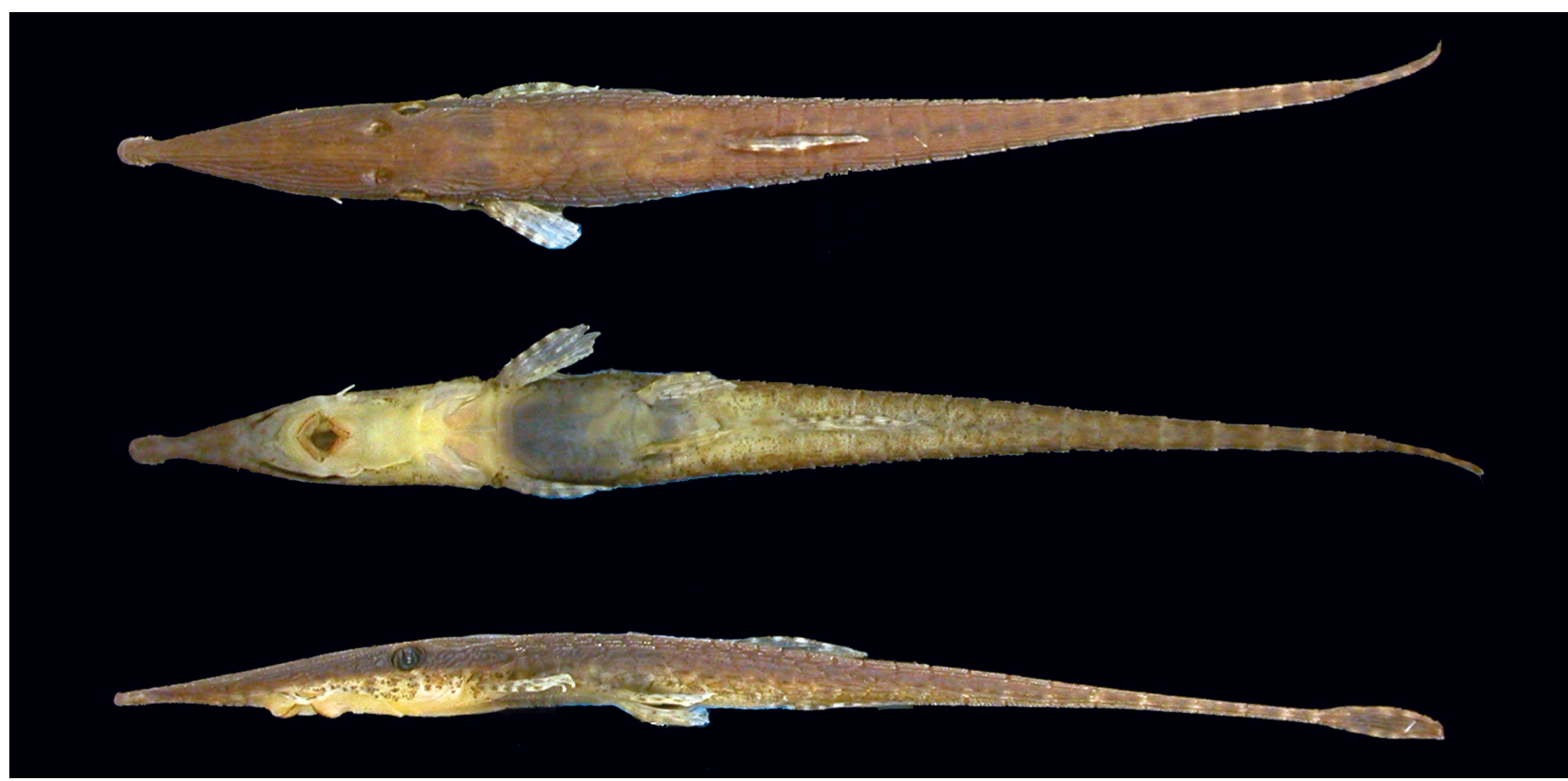

Fig. 1. Acestridium triplax, MPEG 13355, holotype, 55.5 mm SL, female, Igarapé Mutum, Jurutí, Amazonas river Basin, Pará, Brazil. 
functional series. Dentary with 15 to 24 (mean=20, $n=31$ ) bilobed teeth in functional series. All teeth with uneven cusps, with reddish-brown tip. Mesial cusp longer and wider than lateral one.

Abdomen fully plated except for region of pectoral girdle. One series of middle abdominal plates between lateral abdominal plates. Preanal plate wide. Posterior most lateral abdominal plate, in contact with preanal plate, narrow (Fig.4). Three to seven (mean=4.5, $\mathrm{n}=31$ ) lateral abdominal plates on each side. One median prenucal plate and one nucal plate anterior to dorsal fin. Postdorsal plates 13 to $16($ mean $=14, n=31)$. Thirteen to $15($ mean $=14, n=31)$ postanal plates. Four lateral series of plates, mid-dorsal series absent. Parieto-supraoccipital bone and predorsal plates smooth, without ridges.
Dorsal-fin rays i,7. Posterior margin of dorsal fin straight or slightly rounded, with first or second branched ray longest. Tip of dorsal fin, when depressed, reaching third plate posterior to fin base. Dorsal-fin spinelet absent. Pectoral-fin rays I,6. Pectoral spine thick, without serrae or slightly serrate on inner margin, reaching beyond middle of first branched ray. Posterior margin of pectoral fin rounded, with longest first or second branched ray not reaching to pelvic-fin origin. Pelvic-fin rays i,5. Unbranched ray very thick with enlarged odontodes turned mesially. Posterior margin of pelvic fin rounded; second, third, or fourth branched ray longest, not reaching to anal-fin origin. Anal-fin rays i,5. Anal unbranched ray reaching slightly beyond middle of first branched ray. Posterior margin of anal fin rounded, with first, second, or third branched ray longest. Tip of anal fin, when depressed,

Table 1. Descriptive morphometrics of holotype and paratypes of Acestridium triplax. Values are given as percents of standard length or head length. SD = standard deviation.

\begin{tabular}{|c|c|c|c|c|c|c|}
\hline & Holotype & $\mathrm{N}$ & Min & Max & Mean & $\mathrm{SD}$ \\
\hline Standard length (mm) & 55.5 & 30 & 45.3 & 55.4 & 49.8 & - \\
\hline \multicolumn{7}{|c|}{ Percents of Standard Length } \\
\hline Predorsal length & 49.6 & 30 & 42.7 & 51.2 & 48.7 & 1.4 \\
\hline Postdorsal length & 52.4 & 30 & 42.1 & 47.9 & 44.9 & 1.3 \\
\hline Postanal length & 48.8 & 30 & 41.0 & 45.6 & 43.4 & 1.2 \\
\hline Body width at dorsal-fin origin & 7.8 & 30 & 7.1 & 9.1 & 8.0 & 0.4 \\
\hline Body depth at dorsal-fin origin & 5.6 & 30 & 5.4 & 6.5 & 5.9 & 0.3 \\
\hline Body width at anal-fin origin & 7.2 & 30 & 6.6 & 8.4 & 7.5 & 0.4 \\
\hline Body depth at anal-fin origin & 4.8 & 30 & 4.2 & 5.7 & 5.2 & 0.3 \\
\hline Preventral length & 48.2 & 30 & 37.6 & 49.2 & 47.3 & 2.2 \\
\hline Supraoccipital-dorsal fin distance & 15.0 & 30 & 13.7 & 17.1 & 15.5 & 0.8 \\
\hline Minimum depth of caudal peduncle & 1.1 & 30 & 1.0 & 1.2 & 1.1 & 0.1 \\
\hline Length of dorsal-fin spine & 12.4 & 29 & 9.8 & 13.4 & 11.6 & 0.9 \\
\hline Length of pectoral-fin spine & 7.4 & 30 & 6.7 & 9.1 & 7.6 & 0.6 \\
\hline Length of first ventral-fin ray & 6.9 & 30 & 5.8 & 7.9 & 6.7 & 0.5 \\
\hline Length of first anal-fin ray & 8.8 & 30 & 7.8 & 10.2 & 8.8 & 0.6 \\
\hline Snout tip to eye distance & 25.9 & 30 & 20.2 & 22.5 & 21.3 & 0.6 \\
\hline Pectoral-fin origin to pelvic-fin origin distance & 10.4 & 30 & 10.3 & 12.3 & 11.2 & 0.5 \\
\hline Eye to dorsal-fin origin distance & 22.7 & 30 & 21.9 & 26.3 & 23.7 & 0.8 \\
\hline Oral disk width & 6.7 & 30 & 6.1 & 8.4 & 7.1 & 0.6 \\
\hline Head length & 33.9 & 30 & 31.0 & 34.1 & 32.4 & 0.8 \\
\hline \multicolumn{7}{|c|}{ Percents of Head Length } \\
\hline Head depth & 17.3 & 30 & 17.6 & 22.5 & 19.4 & 1.2 \\
\hline Head width & 27.0 & 30 & 27.8 & 33.6 & 30.3 & 1.3 \\
\hline Interorbital width & 17.4 & 30 & 17.3 & 21.2 & 19.5 & 1.1 \\
\hline Length of lower armored snout & 25.6 & 30 & 16.7 & 25.9 & 22.6 & 2.4 \\
\hline Maximum eye diameter & 7.9 & 30 & 7.6 & 9.9 & 8.6 & 0.6 \\
\hline Length of postorbital head & 24.9 & 30 & 22.6 & 27.9 & 24.9 & 1.3 \\
\hline
\end{tabular}

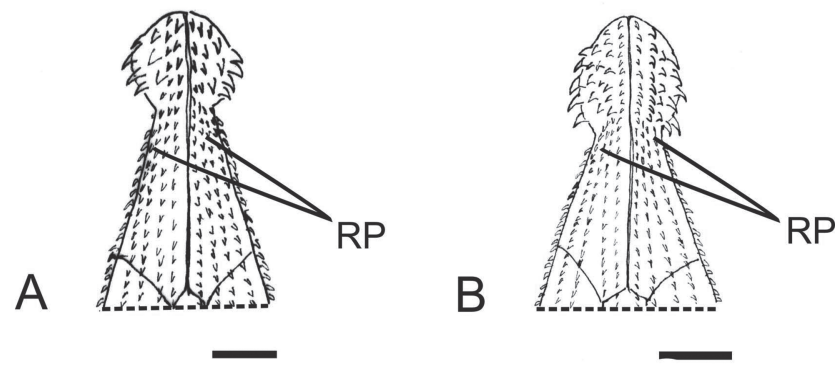

Fig. 2. Spatulate projection of snout. A. Acestridium triplax; B. Acestridium dichromum. RP: rostral plates. Scale: $1 \mathrm{~mm}$.

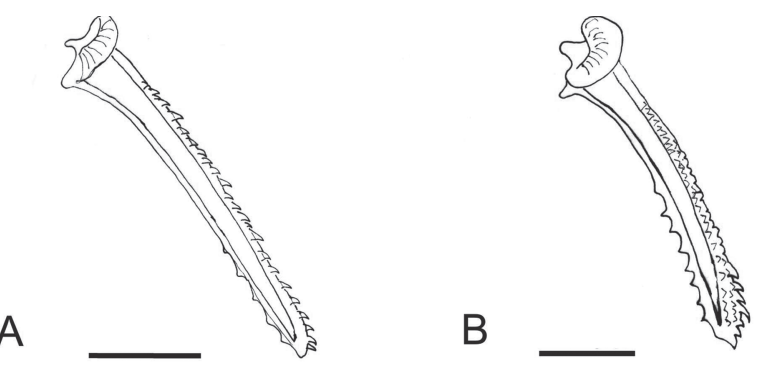

Fig. 3. Pectoral spine. A. Acestridium triplax; B. Acestridium dichromum. Scale: $1 \mathrm{~mm}$. 
reaching third or fourth plate posterior to fin base; two or three ventral plates along its base. Posterior margin of caudal fin truncate or slightly concave; principal caudal-fin rays i,12,i. Adipose fin absent.

Color in alcohol. Dorsum light brown with short stripes of dark pigmentation running between longitudinal rows of odontodes. Dark stripe starts about half distance between tip of snout and eye and runs along side of head through eye, becoming less distinct as it reaches body; stripe becomes indistinct at midbody. Some dark dots sometimes present on sides of head, below dark stripe; on maxillary barbel and upper lip. Ventral side yellowish. Body scarcely pigmented ventrally from anal to caudal fin. Snout with brown background ventrally. Upper lip and snout lightly pigmented. Except for caudal fin, all spine or unbranched rays yellowish tan with round black spots distributed regularly; interradial membranes hyaline. Caudal-fin rays with numerous dark spots which sometimes form 1-2 dark bands, spines with round black spots, distributed regularly, arranged in rows. Dark spots at base of caudal fin.

Sexual dimorphism. Males of Acestridium triplax have conspicuous urogenital papilla, immediately posterior to anal opening, not present in females.

Ontogeny. Many structures vary ontogenetically in Acestridium triplax. The general aspect of juveniles (23.8$28.9 \mathrm{~mm} \mathrm{SL}$ ) resembles Sturisoma species. Young specimens are intensely pigmented, especially showing a dark stripe beginning at the snout tip and running along side of head through eye and becoming less conspicuous at midbody. In juvenile specimens the lower lip is very large with filiform, marginal papillae. Lower lip gradually forms with the upper lip the round mouth typical of Acestridium, with both lips covered by globular papillae. In the smallest specimens, the snout is short and the globular protuberance at snout tip is absent. As noted by Aquino \& Schaefer (2002) for Oxyropsis,

A

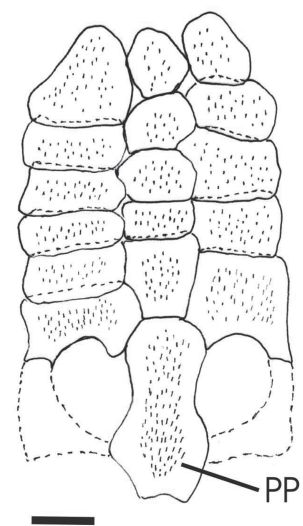

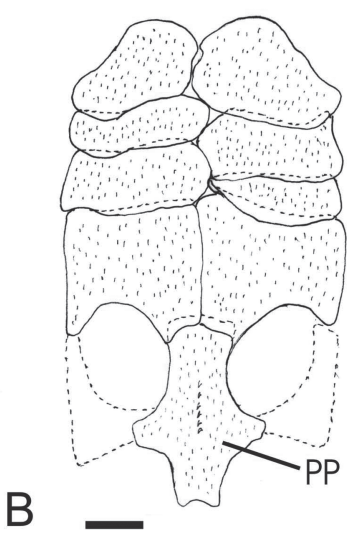

Fig. 4. Abdominal and preanal plates. A. Acestridium triplax; B. Acestridium dichromum. PP: preanal plate. Scale: $1 \mathrm{~mm}$. the abdominal plates are absent in the smaller specimens and have been seen in a specimen of $28.9 \mathrm{~mm} \mathrm{SL}$. In this specimen small lateral abdominal plates are at the lateralmost sector of the abdomen, and the series of middle abdominal plates is represented by small, loose platelets, not contacting each other. The prenucal and nucal plates are seen in specimens from $23.8 \mathrm{~mm} \mathrm{SL}$, the smallest we have.

Distribution and habitat. Known only from small, forest creeks near Juruti, Pará State, lower rio Tapajós drainage, Amazon River basin, Brazil. These creeks are usually shallow (0.3-1.0 $\mathrm{m}$ deep, 5-10 m wide), with sandy bottom, clear or slightly black water, moderate water current, and dense aquatic and marginal vegetation.

Etymology. The species epithet triplax from the Greek tri, three, and plax, plate, referring to the three series of abdominal plates present in the new species.

\section{Discussion}

Most loricariids have what Schaefer (1987) called the nucal plate, the exposed dorsal portion of the supraneural associated to the first dorsal-fin pterygiophore. The connecting bone usually connects the distal portion of the first rib to the lateral margins of the nucal plate and/or the transversal process of the second dorsal-fin pterygiophore. In Acestridium species there are one to three additional dermal plates anterior to the nucal plate, herein called prenucal plates. The prenucal plates are approximately hexagonal and bear ventromedial keels which contact the dorsal margin of the neural arches of the vertebrae six through twelve, being firmly articulated to each other and to the nucal plate. In Acestridium, the connecting bone links the distal portion of the first rib to the anterior most prenucal plate. Among hypoptopomatins, a prenucal plate is also present in Niobichthys.

Material examined: Acestridium discus: Brazil, Amazonas State: FMNH 54339, holotype, $69.1 \mathrm{~mm}$ SL, igarapé de Cachoeira Grande, near Manaus. FMNH 54340, 1 paratype, $52.1 \mathrm{~mm} \mathrm{SL}$, same data as FMNH 54339. CAS 52153, 1 paratype, $49.4 \mathrm{~mm}$ SL, igarapé do Maia, Iraue, Manaus. CAS-SU 64095, 8, 41.9-59.4 mm SL, igarapé da Mãe Joana into rio Negro near Manaus. MHNG 2557.055, 5, 42.2-44.7 mm SL, rio Araçá, rio Negro basin. MHNG 2575.61, 2, 31.2-39.7 mm SL, rio Cuiuni, rio Negro basin. MZUSP 85320, 7+2 c\&s, 26.8-56.6 mm SL, igarapé Barroso, tributary to rio Preto da Eva on Francisco Mendes road, approx. $2^{\circ} 44^{\prime} \mathrm{N} 59^{\circ} 38^{\prime} \mathrm{W}$. MZUSP $85321,12+2$ c\&s, 22.4-62.4 mm SL, bathing spot at igarapé do Manu, rio Preto da Eva basin, approx. $2^{\circ} 40^{\prime} \mathrm{N} 59^{\circ} 42^{\prime} \mathrm{W}$. MZUSP $85322,9+1$ c\&s, 16.3-64.5 mm SL, igarapé nearby sitio Bom Jesus, km 13 of Francisca Mendes road rio Preto da Eva basin, approx. $2^{\circ} 45^{\prime} \mathrm{N} 59^{\circ} 37^{\prime} \mathrm{W}$. MZUSP 85323, 6+1 c\&s, 18.8-55.3 mm SL, rio Preta da Eva, $15 \mathrm{~km} \mathrm{~N}$ of Rio Preto da Eva, approx. $2^{\circ} 35^{\prime} \mathrm{N}$ $59^{\circ} 45^{\prime} \mathrm{W}$. MZUSP 88878, 6, 30.4-64.3 mm SL, bathing stop ca 2 $\mathrm{km}$ downstream of Rio Preto da Eva, 242'42"S 5941'36"W. MZUSP 88944, 7, 32.8-65.1 mm SL, creek tributary to rio Preto da Eva, after the bathing spot of Encanto da Mata, 2०37'10"S 5944’30"W. MZUSP 88962, 15, 19.9- 62.1 mm SL, rio Preto da 
Eva, ca $4 \mathrm{~km}$ upstream of town, 240'49"S 5943'15"W. MZUSP 88966, 4, 35.4-66.9 mm SL, creek tributary to rio Preto da Eva, after the bathing spot of Encanto da Mata, $2^{\circ} 37^{\prime} 10^{\prime \prime S} 59^{\circ} 44^{\prime} 30^{\prime \prime W}$. MZUSP 88986, 10, 17.0-63.4 mm SL, creek on road from Rio Preto da Eva to Pousada do Paraíso, 245'34"S 59³9'49"W. Venezuela, Amazonas State: USNM 269947, 2, 43.6-46.6 mm SL, shore of rio Negro, ca half hour above San Carlos do Rio Negro, Departamento Rio Negro, approx. $1^{\circ} 58^{\prime} \mathrm{N} 67^{\circ} 04^{\prime} \mathrm{W}$. ANSP 165830 , 1, $44.0 \mathrm{~mm} \mathrm{SL}$, rio Matiyure, at Achaguas, approx. $7^{\circ} 45^{\prime} \mathrm{N} 68^{\circ} 11^{\prime} \mathrm{W}$. Acestridium colombiensis: Colombia: FMNH 105169, 10 paratypes, 38.0-45.6 mm SL, lagoon $1 \mathrm{~km}$ upriver from Puerto Inirida, rio Orinoco drainage, Guainia. FMNH 115255, holotype, 50.9 mm SL, same locality as FMNH 105169. INHS 99093, 2 paratypes, 37.9$43.2 \mathrm{~mm} \mathrm{SL}$, lagoon $1 \mathrm{~km}$ upriver from Puerto Inirida, rio Orinoco drainage, Guainia.

Acestridium martini: Venezuela, Amazonas State: ANSP 160644, 1, $40.8 \mathrm{~mm}$ SL, rio Sipapo, backwater channel behind sandbar 6-7 km above Pendare, approx. $4^{\circ} 51^{\prime} \mathrm{N} 67^{\circ} 43^{\prime} \mathrm{W}$. ANSP 160701, 8, 31.9$42.9 \mathrm{~mm}$ SL, rio Sipapo, ca. $6 \mathrm{~km}$ upstream of Pendare, approx. $4^{\circ} 51^{\prime} \mathrm{N} 67^{\circ} 43^{\prime}$ 'W. ANSP 165831, 6, 43.3-62.8 mm SL, Caño Horeda, at border of Bolívar-Amazonas Territories, ca $68 \mathrm{~km} \mathrm{NE}$ of Puerto Ayacucho, approx. $6^{\circ} 08^{\prime} \mathrm{N} 67^{\circ} 22^{\prime} \mathrm{W}$. MCP 35015, 4 + 1 c\&s, 46.5$69.7 \mathrm{~mm}$ SL, rio Sipapo, above Pendare, approx. $2^{\circ} 31^{\prime} \mathrm{N} 66^{\circ} 30^{\prime} \mathrm{W}$. FMNH 85827, 2, 42.4-59.6 mm SL, laguna Titi near Puerto Atabapo (same as San Fernando de Atabapo) on road past airstrip. FMNH 103323, 34, 33.9-64.4 mm SL, rio Sipapo, ca. $1.5 \mathrm{hrs}$. above Pendare, $4^{\circ} 45^{\prime} 24^{\prime \prime} \mathrm{N} 67^{\circ} 43^{\prime} 17^{\prime \prime W}$. FMNH 103324, 8, 42.5-51.0 mm SL, rio Autana at beach below mouth of caño Cabeza de Manteco, $4^{\circ} 48^{\prime} 41^{\prime \prime} \mathrm{N} 67^{\circ} 32^{\prime} 48^{\prime \prime} \mathrm{W}$. FMNH 103325, 25 paratypes, 39.1-66.8 $\mathrm{mm} \mathrm{SL}$, caño Cucurito, ca. $1 \mathrm{~km}$ above mouth in rio Autana, $4^{\circ} 43^{\prime} 48^{\prime \prime} \mathrm{N} \mathrm{67} 7^{\circ} 37^{\prime} 12^{\prime \prime} \mathrm{W}$. FMNH 103555, 20 paratypes, 39.6-65.1 $\mathrm{mm} \mathrm{SL}$, rio Autana at playa Cucurito in front of caño Cucurito, 443'42"N 67³8'07"W. USNM 269945, 2, 42.7-49.5 mm SL, caño Manu, tributary of Casiquiare Canal, approximately $250 \mathrm{~m}$ upstream of Solano, Rio Negro Dept., approx. $2^{\circ} 00^{\prime} \mathrm{N} 66^{\circ} 57^{\prime} \mathrm{W}$. USNM 269946, 2, 40.0-51.6 mm SL, small creek off caño Urami, just upriver of Santa Lucia, Rio Negro Dept., approx. $1^{\circ} 17^{\prime} \mathrm{N} 66^{\circ} 51^{\prime} \mathrm{W}$. USNM 389920, 3, 47.2-59.1 mm SL, caño Chola, where crossed by road from San Carlos de Rio Negro to Solano, Rio Negro Dept., 158'N $67^{\circ} 00^{\prime} \mathrm{W}$. INHS 40425, 1 allotype, $62.0 \mathrm{~mm}$ SL, caño Pozo Azul, rio Orinoco drainage, $5^{\circ} 45^{\prime} 49^{\prime \prime} \mathrm{N} 6^{\circ} 29^{\prime} 21^{\prime \prime W}$. INHS 61564, 6 paratypes, 40.2-57.8 mm SL, caño Pozo Azul, rio Orinoco drainage, 54' 49"N 67²9'21"W. Brazil: MHNG 2576.32, 1, 47.6 mm SL, rio Araçá below confluence of rio Cueiras, rio Negro basin. MHNG 2577.055, 4, 33.7-44.6 mm SL, rio Araçá, rio Negro basin. MZUSP 26820, $3+1 \mathrm{c} \& \mathrm{~s}, 46.6-48.2 \mathrm{~mm} \mathrm{SL}$, rio Cuieiras, Amazonas, rio Negro basin, approx. $2^{\circ} 50^{\prime}$ S 60³0'W. MZUSP 61945, 4, 38.6-54.6 $\mathrm{mm}$ SL, rio Aiuanã, near Santa Isabel do rio Negro (=Tapurucuava). MZUSP 74275, 6+1 c\&s, 41.6-60.5 mm SL, igarapé Jaradá, tributary to rio Cuieiras, ca. $40 \mathrm{~km}$ upstream mouth. MZUSP 77945, 2, 54.4$54.9 \mathrm{~mm} \mathrm{SL}$, rio Aiuanã, tributary to rio Negro. USNM 268903, 3, 36.3-57.5 mm SL, rio Negro at Anavilhanas archipelago. CAS-SU 64202, 2, 46.1-46.8 mm SL, small creek into igarapé Castanha, tributary to rio Negro, ca 2 hrs. by boat upstream from Manaus. Acestridium dichromum: Venezuela, Amazonas State: ANSP 160692 , 1, $40.8 \mathrm{~mm}$ SL, rio Sipapo, $500 \mathrm{~m}$ upstream of Pendare, approx. $4^{\circ} 54^{\prime} \mathrm{N} 67^{\circ} 43^{\prime} \mathrm{W}$. ANSP 161494, 6+2 c\&s, 34.6-50.7 mm SL, outflow stream from series of morichales ca $5.0 \mathrm{~km}$ from mouth of rio Pamoni, approx. $2^{\circ} 48^{\prime} \mathrm{N} 65^{\circ} 53^{\prime} \mathrm{W}$. ANSP 187061, 2+1 c\&s, 32.2-38.8 mm SL, rio Sipapo, ca $6 \mathrm{~km}$ upstream of Pendare, approx. $4^{\circ} 51^{\prime} \mathrm{N}$ 67²4'W. MCP 35016, 3, 37.4-56.1 mm SL, caño Cucurito, ca 1 km upstream mouth of río Autana, approx. $4^{\circ} 44^{\prime} \mathrm{N} 67^{\circ} 41^{\prime} \mathrm{W}$. FMNH
103326, 6 paratypes, 27.2-57.4 mm SL caño Cucurito ca $1 \mathrm{~km}$ above mouth in rio Autana, $4^{\circ} 43^{\prime} 48^{\prime \prime} \mathrm{N} 67^{\circ} 37^{\prime}$ '12'W. FMNH 105326 , $1,59.8 \mathrm{~mm} \mathrm{SL}$, caño Curcurito ca. $1 \mathrm{~km}$ above mouth in rio Autana, $4^{\circ} 43^{\prime} 48^{\prime \prime N} 67^{\circ} 37^{\prime} 12^{\prime \prime W}$. FMNH 105327, 3, 34.4-39.3 mm SL, rio Autana at Playa Cucurito in front of caño Cucurito, $4^{\circ} 43^{\prime} 42^{\prime \prime} \mathrm{N}$ $67^{\circ} 38^{\prime} 07^{\prime \prime} \mathrm{W}$. INHS 27642, 1 paratype, $52.9 \mathrm{~mm}$ SL, caño Topocho at bridge on highway between Puerto Paez and Puerto Ayacucho, 556’39"N 67²2'09"W. INHS 40427, 1 allotype, 44.7 mm SL, Pozo de Lucas, $7 \mathrm{~km}$ behind San Fernando de Atabapo, approx. $4^{\circ} 2^{\prime} \mathrm{N} 67^{\circ} 42^{\prime} \mathrm{W}$. USNM 269949, 25, 27.0-52.0 mm SL, caño Chola, where crossed by road from San Carlos de Rio Negro to Solano, approx. $1^{\circ} 58^{\prime} \mathrm{N} 67^{\circ} 00^{\prime} \mathrm{W}$.

Acestridium sp 1: Brazil, Amazonas State, Humaitá: MCP 37783, 12, 27.9-60.2 mm SL, creek ca $68 \mathrm{~km}$ E of rio Madeira on TransAmazon road, $7^{\circ} 43^{\prime} 58^{\prime \prime S} 62^{\circ} 29^{\prime} 40^{\prime \prime} \mathrm{W}$. MCP 37784, $13+2 \mathrm{c} \& \mathrm{~s}$, 25.2-62.0 $\mathrm{mm}$ SL, rio Traira, ca $35 \mathrm{~km}$ E of rio Madeira TransAmazon road, 7³5'33"S 6244'45"W.

Acestridium sp 2: Brazil, Amazonas State, Humaitá: MCP 37785 , $15+2$ c\&s, 29.0-62.9 mm SL, rio Traira, ca $35 \mathrm{~km}$ E of rio Madeira on Trans-Amazon Road, 7³5'33"S 6244'45"W.

\section{Acknowledgments}

The following colleagues contributed with specimens and/ or hospitality during MSR's visits to the USA: William Fink, Sara Fink, and Douglas Nelson (UMMZ), John Lundberg, Mark Sabaj, and Kyle Luckenbill (ANSP), Scott Schaefer and Barbara Brown (AMNH), Richard Vari, Sandra Raredon, and Jeffrey Williams (USNM), David Catania (CAS), Mark Westneat, Mary Anne Rogers, Susan Mochel, Kevin Swagel, and Philip Willink (FMNH). Special thanks to Michael Retzer (INHS), who kindly provided material of Acestridium under his care, during MSR's visit to the Field Museum of Natural History. Wolmar Wosiacki and Luciano F. Montag (MPEG) collected all the type material and sent us additional information on field data. Osvaldo Oyakawa (MZUSP) sent material for this study. MSR was financed by the All Catfish Species Inventory (NSF-DEB \#0315963) and a postdoctoral fellowship from CNPq (process \# 152041/2004-7). RER is partially financed by CNPq (process \# 301748/2004-7).

\section{Literature Cited}

Aquino, A. E. \& S. A. Schaefer. 2002. Revision of Oxyropsis Eigenmann \& Eigenmann, 1889 (Siluriformes, Loricariidae). Copeia, 2: 374-390.

Boeseman, M. 1971. The "comb-toothed" Loricariinae of Surinam, with reflections on the phylogenetic tendencies within the Family Loricariidae (Siluriformes, Siluroidei). Zoologische Verhandelingen, 116: 1-56.

Reis, R. E., S. O. Kullander \& C. J. Ferraris, Jr. (eds). Check List of the Freshwater Fishes of South and Central America. Porto Alegre, Edipucrs, 729p.

Retzer, M. E., L. G. Nico \& F. Provenzano. 1999. Two new species of Acestridium (Siluformes: Loricariidae) from southern Venezuela, with observations on camouflage and color change. Ichthyological Exploration of Freshwaters, 10 (4): 313-326. 
Schaefer, S. A. 1987. Osteology of Hypostomus plecostomus (Linnaeus), with a phylogenetic analysis of the loricariid subfamilies. Contributions in Science, Natural History Museum of Los Angeles County, 394: 1-31.

Schaefer, S. A. 1991. Phylogenetic analysis of the loricariid subfamily Hypoptopomatinae (Pisces: Siluroidei: Loricariidae), with comments on generic diagnoses and geographic distribution. Zoological Journal of Linnean Society, 102: 1-41.

Schaefer, S. A. 1997. The Neotropical cascudinhos: Systematics and biogeography of the Otocinclus catfishes (Siluriformes: Loricariidae). Proceedings of the Academy of Natural Sciencies of Philadelphia, 148:1-120.

Taylor, W. R. \& G. C. Van Dyke. 1985. Revised procedures for staining and clearing small fishes and other vertebrates for bone and cartilage study. Cybium, 9:107-119.

Submitted October 2007 Accepted November 2007 